\title{
The synergy between endoscopic assistance and extraoral approach in subcondylar fracture repair: a report of 13 cases
}

\author{
Lütfi Eroğlu, M.D., ${ }^{1}$ İbrahim Alper Aksakal, M.D., ${ }^{1}$ Musa Kemal Keleş, M.D., ${ }^{1}$ \\ Çağlayan Yağmur, M.D., ${ }^{2}$ Ozan Aslan, M.D., ${ }^{3}$ Tekin Şimşek, M.D. ${ }^{1}$
}

${ }^{1}$ Department of Plastic, Reconstructive and Aesthetic Surgery, Ondokuz Mayis University Faculty of Medicine, Samsun ${ }^{2}$ Department of Plastic, Reconstructive and Aesthetic Surgery, Samsun Training and Research Hospital, Samsun ${ }^{3}$ Department of Plastic, Reconstructive and Aesthetic Surgery, Samsun Gazi Public Hospital, Samsun

\begin{abstract}
BACKGROUND: We aimed to present the primary experience of one surgeon with a new surgical technique performed on the first 13 cases and to evaluate outcomes following an extraoral endoscopic approach to subcondylar fractures.

METHODS: Fifteen subcondylar fractures in 13 patients, who were treated at Ondokuz Mayis University Hospital between January 2010 and June 20I I, were included in this study. Patients were operated on using either endoscopic or open approach.

RESULTS: Rigid plate fixation was completed endoscopically using extraoral approach in nine fractures, while six fractures were plated by conversion to a full-open approach. In all six fractures that could not be fixed endoscopically, the proximal fragments were medially displaced, whereas seven of nine fractures that were successfully fixed endoscopically were laterally displaced.
\end{abstract}

CONCLUSION: An extraoral endoscopic approach for subcondylar fractures is feasible and can be carried out with decreased morbidity. This approach is recommended for those with limited experience in endoscopy to treat low laterally displaced subcondylar fractures as their initial cases.

Key words: Endoscopy, endoscopic assistance, subcondylar fracture, subcondylar fracture treatment.

\section{INTRODUCTION}

Subcondylar fractures of the mandible are common and account for $9-45 \%$ of all mandibular fractures; treatments for these fractures remain controversial. ${ }^{[1-8]}$ Although closed reduction and maxillomandibular fixation is the method most widely employed to treat subcondylar fractures, accurate reduction of the fracture and anatomically restoring condylar position are rarely achieved. Open reduction and internal fixation (ORIF) is a reliable method for anatomical restoration of condylar position and for minimizing the risk of malocclu-

Address for correspondence: Çağlayan Yağmur, M.D. Samsun Eğitim ve Araştırma Hastanesi, Merkez, Samsun, Turkey Tel: +90 362 - 3 III I I5 E-mail: caglayanyagmur@gmail.com

Qucik Response Code Ulus Travma Acil Cerr Derg

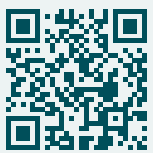

2013;19(5):434-440

doi: $10.5505 /$ tjtes.2013.77292

Copyright 2013

TJTES sion, internal derangement and degenerative osteoarthritis. [9] However, ORIF has some major drawbacks, such as poor access and visualization, facial nerve deficits, facial scarring, salivary fistulas, and delayed functional rehabilitation. Many open subcondylar fracture repair techniques to minimize these limitations and complications have been described. ${ }^{[3]}$

The endoscopic approach to the repair of subcondylar fractures was first described by Jacobovicz et al. in 1998. [9] Subsequently, this minimally invasive technique was advocated by many authors for fracture management with a potential for decreased patient morbidity. ${ }^{[10]}$

Endoscopic subcondylar fracture repair has evolved to achieve equivalent or superior results with decreased morbidity. Compared with open techniques (preauricular approach), the endoscopic approach to the condylar region remains extracapsular and does not affect cartilage or synovial fluid. ${ }^{\left[{ }^{[I]}\right.}$ The purpose of this study was to present the primary experience of one surgeon with an endoscopic surgical technique performed on the first 13 cases and to evaluate outcomes following an extraoral endoscopic approach to subcondylar fractures. 


\section{MATERIALS AND METHODS}

This study was approved by the Ondokuz Mayis University Hospital Institutional Review Board, and all participants signed an informed consent agreement. Fifteen subcondylar fractures in 13 consecutive patients, who were treated at Ondokuz Mayis University Hospital between January 2010 and June 20 II, were included in this study. All operations were performed by one surgeon (LE). The total follow-up period for patients was 18 months.

Ten males (77\%) and three females (23\%), with an age range of 23-59 years, were included. The mechanisms of the fractures included falls ( 6 cases), motor vehicle accidents ( 6 cases), and assault (I case). Two patients had bilateral subcondylar fractures. The subcondylar fractures were dislocated medially in seven cases and laterally in the remainder. Ten patients had concurrent facial fractures (Table I).

The main findings in the cases diagnosed as subcondylar fractures were pain, malocclusion, open bite, and mandibular asymmetry. Localization and type of fractures, degree of displacement, and the presence of additional facial fractures were evaluated by panoramic radiographs and computed tomography (CT) scans. The procedures were performed under general anesthesia using endoscopic instruments $\left(30^{\circ}\right.$ angled 4-mm diameter straight endoscope). Five of the 15 fractures were explored using two ports (submandibular and intraoral), whereas nine were explored through a single submandibular port. One fracture was explored by using a previous laceration.

\section{Surgical Technique}

It is recommended that the patient be in the supine position and nasotracheally intubated. This positioning allows the
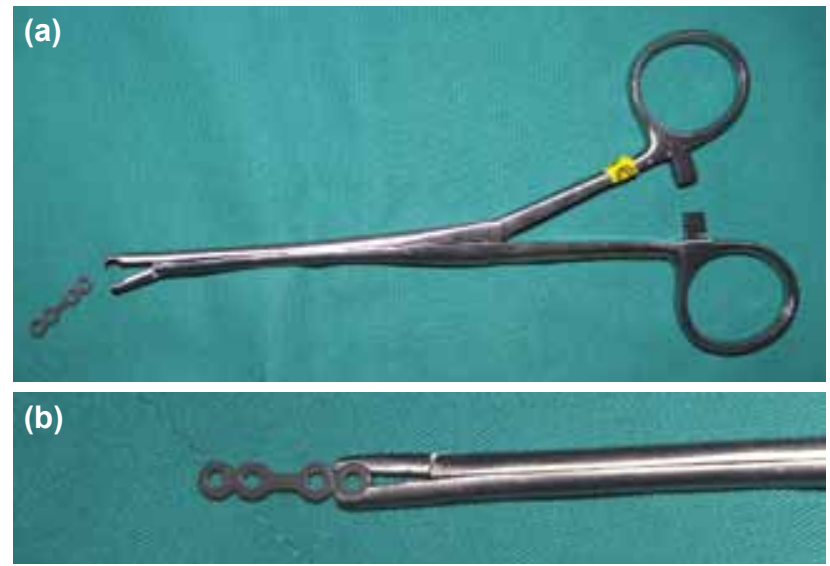

Figure 1. (a) Our specially designed plate holder clamp. (b) The head part of the clamp is compatible with the plate. This enables the surgeon to perform fine manipulations with great ease.

surgeon and assistant to stand on either side of the head of the patient.

Visualization requires an endoscope and a camera attachment. The endoscopic view is projected on a video monitor that can be viewed by both the surgeon and the assistant. The surgeon should also have access to appropriate instrumentation. Some specialized instruments have been designed specifically to facilitate this procedure (Fig. Ia, b).

Arch bars were applied (if the patient was dentate) for postoperative occlusal training and mandibulomaxillary fixation (MMF). If there were any other fractures in the mandible, these were repaired first. All of our endoscopic surgery was performed using a submandibular incision combined with an intraoral incision in initial cases. A preauricular incision was used for the open reductions (bail out procedure) (Table 2).

Table I. Patients with concurrent facial fractures

\begin{tabular}{cclll}
\hline No & Age & Fracture & Dislocation & Concurrent fracture \\
\hline I & 38 & $\begin{array}{l}\text { Left } \rightarrow \text { Subcondylar } \\
\text { Right } \rightarrow \text { Subcondylar }\end{array}$ & $\begin{array}{l}\text { Right } \rightarrow \text { Medial } \\
\text { Left } \rightarrow \text { Lateral }\end{array}$ & Yes \\
2 & 56 & Left $\rightarrow$ Subcondylar & Lateral & No \\
3 & 38 & Right $\rightarrow$ High subcondylar & Medial & Yes \\
4 & 26 & Right $\rightarrow$ Subcondylar & Lateral & Yes \\
5 & 47 & Left $\rightarrow$ Subcondylar & Lateral & Yes \\
6 & 23 & Left $\rightarrow$ Subcondylar & Medial & Yes \\
7 & 24 & Left $\rightarrow$ Subcondylar & Lateral & No \\
8 & 32 & Right $\rightarrow$ Subcondylar & Medial & Yes \\
9 & 24 & Right $\rightarrow$ Subcondylar & Right $\rightarrow$ Medial & Yes \\
& & Left $\rightarrow$ Subcondylar & Left $\rightarrow$ Lat & No \\
10 & 44 & Right $\rightarrow$ Subcondylar & Lateral & Yes \\
11 & 49 & Left $\rightarrow$ Subcondylar & Medial & Yes \\
12 & 59 & Right $\rightarrow$ Subcondylar & Lateral & Yes \\
\hline 13 & 45 & Left $\rightarrow$ Subcondylar & Medial & \\
\hline
\end{tabular}


Table 2. Bail-out procedure

\begin{tabular}{cllc}
\hline No & Incision(s) & Operation Type(s) & Mini-plate(s) \\
\hline I & Right $\rightarrow$ Submandibular-Intraoral & Right $\rightarrow$ Endoscopic-Open & Right (I) \\
& Left $\rightarrow$ Submandibular-Preauricular & Left $\rightarrow$ Endoscopic $(I)$ \\
2 & Submandibular & Endoscopic & I \\
3 & Submandibular-Preauricular & Endoscopic-Open & 2 \\
4 & Submandibular-Intraoral & Endoscopic-Open & I \\
5 & Submandibular-Intraoral & Endoscopic-Second & 2 \\
6 & Submandibular-Intraoral & Endoscopic & 2 \\
7 & AN (own incision) & Endoscopic & 2 \\
8 & Submandibular-Intraoral & Endoscopic & I \\
9 & Right $\rightarrow$ Submandibular, Preauricular & Right $\rightarrow$ Endoscopic-Open & Right (I) \\
& Left $\rightarrow$ Submandibular & Left $\rightarrow$ Endoscopic & Left (2) \\
10 & Submandibular & Endoscopic & I \\
II & Submandibular-Preauricular & Endoscopic-Open & I \\
I2 & Submandibular & Endoscopic & I \\
I3 & Submandibular-Preauricular & Endoscopic-Open & I \\
\hline
\end{tabular}

After the injection with a hemostatic agent, I\% lidocaine with I:100.000 epinephrine, a $1.5-2 \mathrm{~cm}$ incision was made one finger-breadth below a line from the mandibular angle. The angular part of the mandible was dissected meticulously using a fine-tipped scissor to protect the marginal mandibular nerve. A blind subperiosteal dissection was then performed to create an optical cavity. A lag screw was passed through a $1.5-\mathrm{mm}$ drill hole at the mandibular angle to allow the surgeon to distract the distal segment. The fracture lines were identified endoscopically. A long-handled, narrowtipped clamp was used to grasp the condylar neck and to position the condylar head in the fossa. After ensuring that the fractures were reduced, fixation was achieved by placing titanium mini-plates and screws via a preauricular stab incision and trocar.

\section{RESULTS}

Fifteen subcondylar fractures were explored in 13 patients using an endoscopic approach. Two of the 13 patients had bilateral fractures. Rigid plate fixation was completed endoscopically in nine fractures (Fig. 2); six fractures that could not be reduced endoscopically were plated by conversion to a fullopen approach (bail-out procedure). According to the postoperative radiographs, only one endoscopically operated case had inadequate reduction on one side. That patient underwent re-fixation three days later, which ultimately resulted in a successful functional outcome with normal occlusion as with the remaining endoscopically fixed fractures.

Mandibulomaxillary fixation (MMF) was used for 14 days in six cases in whom stabilization was questionable. All patients in this series ultimately developed normal occlusion and function.

In all six fractures that could not be fixed endoscopically, the proximal fragments were medially displaced, whereas seven of nine fractures that were successfully fixed endoscopically were laterally displaced. Two fractures that were fixed endoscopically were minimally medially displaced. Ten subcondylar fractures were fixed with one mini-plate. Five cases underwent fixation with two mini-plates (Table 2).

The mean operating time was 150 minutes (min), including MMF.

Panoramic radiographs and $\mathrm{CT}$ scans (coronal, axial, and three-dimensional CT) were taken postoperatively. Adequate consolidation of the fracture was observed in all patients at the end of the follow-up period (Fig. 3).

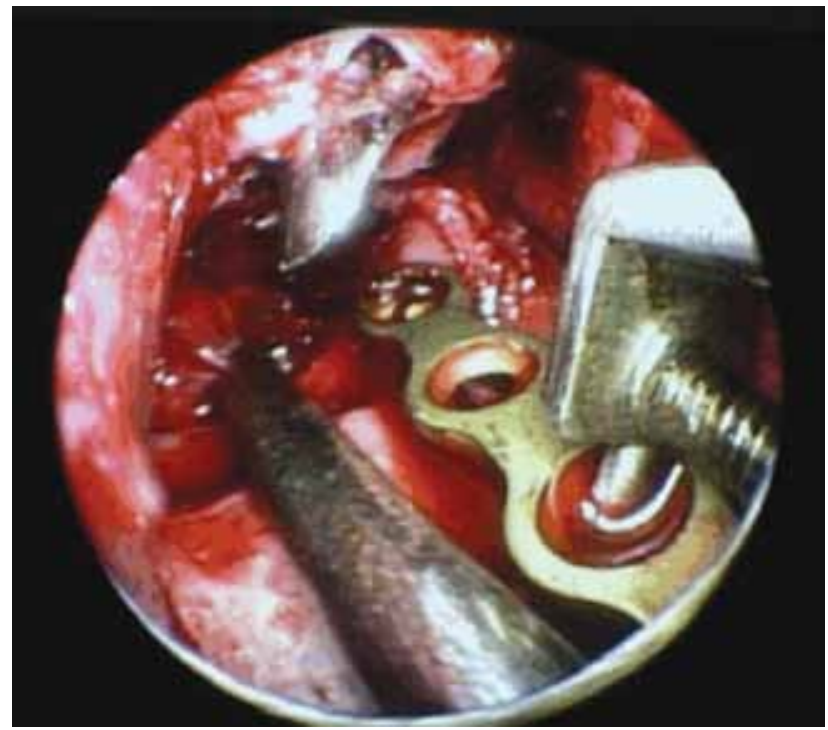

Figure 2. Endoscopic assistance in rigid plate fixation. 

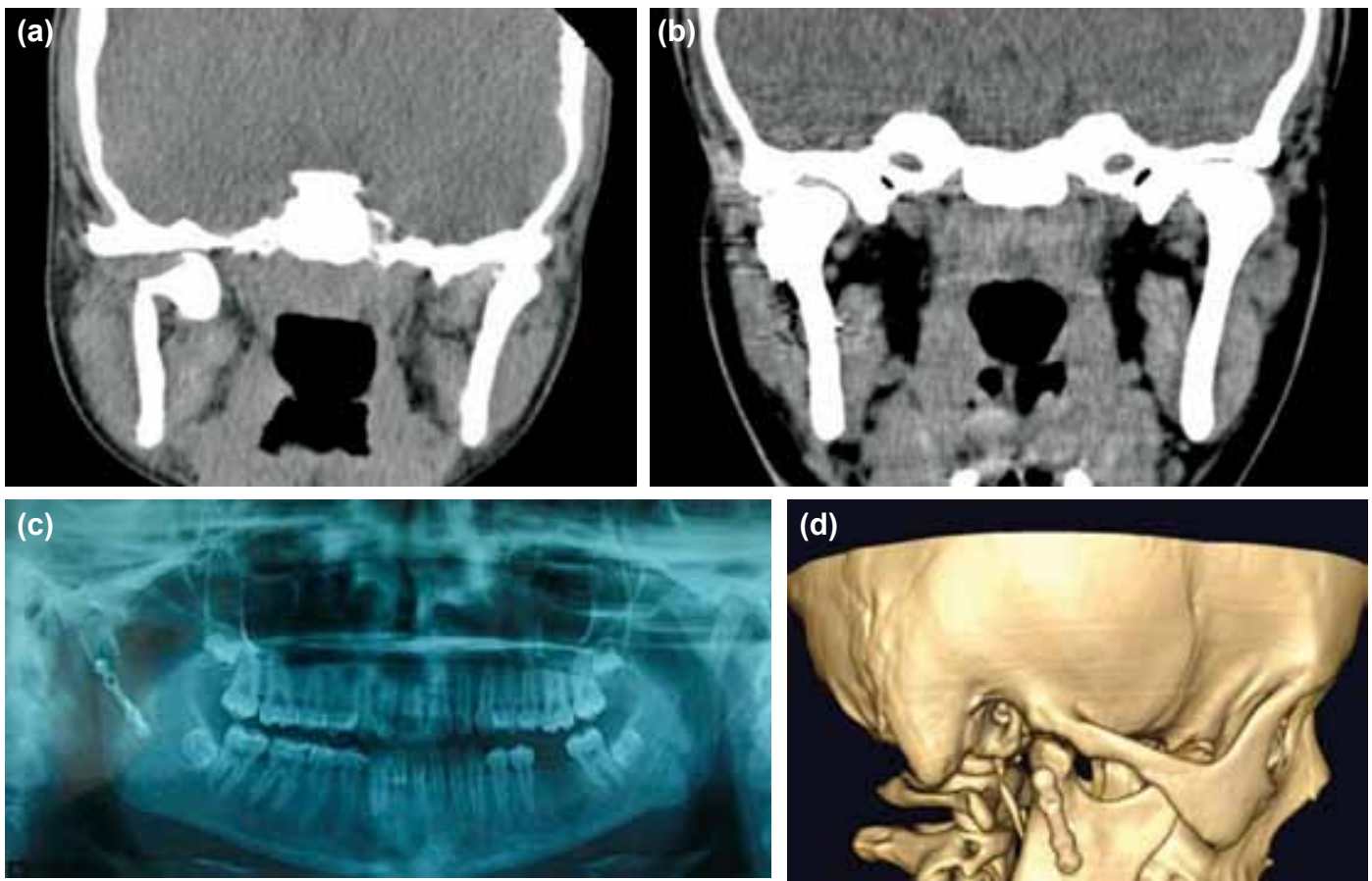

Figure 3. (a) Right-sided medially displaced subcondylar fracture in a coronal section CT scan. Coronal (b), panoramic mandibular (c) and 3D-reconstructed CT scan image (d) of the same fracture after endoscopically assisted fixation using an external approach.

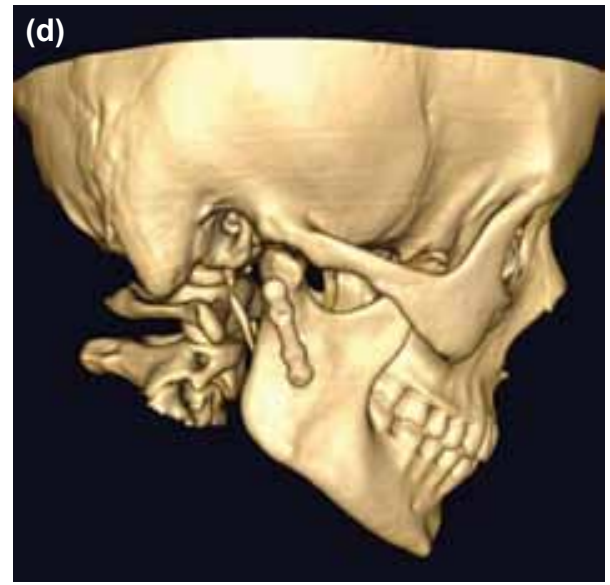

Facial nerve weakness was detected in two of six patients who underwent open technique (33\%) and in one of nine cases who underwent endoscopic technique (1 I\%). Normal nerve function had recovered before the postoperative 5 th month in these patients in both groups. One patient (7\%) who underwent open technique developed a visible scar. The mean maximal interincisal mouth opening was $42.28 \mathrm{~mm}$ in endoscopically assisted operations. Three patients had a temporomandibular joint (TMJ) click; two of them had undergone an open technique. Three patients who underwent open technique complained of a persistent headache and one patient complained of TMJ pain (Table 3).

Table 3. Complications

\begin{tabular}{|c|c|c|c|c|c|c|c|}
\hline No & TFNW & Vs & MO (mm) & Click & Headache & TMJ Pain & Operation technique \\
\hline I & No & No & 40 & Yes (Right) & No & No & $\begin{array}{l}\text { Right } \rightarrow \text { Endoscopic-Open, } \\
\text { Left } \rightarrow \text { Endoscopic }\end{array}$ \\
\hline 2 & No & No & 39 & No & No & No & Endoscopic \\
\hline 3 & Yes & Yes & 38 & No & Yes & No & Endoscopic-Open \\
\hline 4 & No & No & 46 & No & No & No & Endoscopic-Open \\
\hline 5 & No & No & 46 & No & No & No & Endoscopic \\
\hline 6 & Yes & No & 43 & Yes & No & No & Endoscopic \\
\hline 7 & No & No & 44 & No & No & No & Endoscopic \\
\hline 8 & No & No & 41 & No & No & No & Endoscopic \\
\hline 9 & Yes (Right) & No & 53 & No & Yes (Right) & Yes (Right) & $\begin{array}{l}\text { Right } \rightarrow \text { Endoscopic-Open, } \\
\text { Left } \rightarrow \text { Endoscopic }\end{array}$ \\
\hline 10 & No & No & 40 & No & No & No & Endoscopic \\
\hline 11 & No & No & 42 & No & Yes & No & Endoscopic-Open \\
\hline 12 & No & No & 43 & No & No & No & Endoscopic \\
\hline 13 & No & No & 44 & Yes & No & No & Endoscopic-Open \\
\hline
\end{tabular}

TFNW: Transient facial nerve weakness; Vs: Visible scar; MO: Mouth opening; TMJ Pain: Temporomandibular joint pain. 


\section{DISCUSSION}

The criteria for successful treatment of mandibular subcondylar fractures include reestablishment of preinjury occlusion, pain-free jaw opening of $\geq 40 \mathrm{~mm}$, good excursion of the jaw in all directions, minimal facial scarring, and facial symmetry. ${ }^{[12,13]}$ The indications for open reduction or nonsurgical treatment remain controversial, and closed reduction remains the most widely used method. ${ }^{[3,6,8]}$ Although superior functional outcomes following anatomical reduction compared with nonsurgical treatment have been reported for displaced fractures, ${ }^{[3,4,7,8]}$ there is a relatively high risk of injury to the facial nerve, poor access and visualization, facial scaring, salivary fistulas, and delayed functional rehabilitation ${ }^{[3,14,15]}$ Endoscopic techniques using limited incisions have been described to minimize complications related to a surgical approach. Minimally invasive techniques achieve equivalent or superior results with decreased morbidity when compared with standard techniques. ${ }^{[12,16-25]}$ Five of our patients who were operated on using open technique had pain (headache or TMJ pain) or TMJ click, while one patient in whom endoscopic approach was used had TMJ click (Table 3). This might be due to the endoscopic approach, which remains extracapsular and does not affect cartilage or synovial fluid. [" ${ }^{I I]}$ Two endoscopic techniques to approach subcondylar fractures have been developed. ${ }^{[27]}$ One technique uses an intraoral incision followed by a dissection along the mandibular ramus. ${ }^{[16-22]}$ The second technique uses an incision inferior to the mandibular angle as a mini-Risdon type of approach. ${ }^{[24-27]} \mathrm{Kellman}^{[20]}$ and Mueller et al. ${ }^{[23]}$ reported the technical details of endoscopic approaches. Kellman also described the main incisions (intraoral and submandibular) as major ports; that is, a larger incision through which endoscopic visualization is performed.

Transoral approaches have been used with great success to treat subcondylar fractures. ${ }^{[16,17,19,21,22,29-34]}$ The transoral approach, which is minimally invasive, can reduce a subcondylar fracture without facial scarring or facial nerve injury. Troulis and Kaban described an extraoral endoscopic approach to manage subcondylar fractures. ${ }^{[25]}$ They reported that a submandibular incision significantly reduces dissection, bleeding, and swelling, and they suggested that this allows better visualization and a more comfortable orientation, making the learning curve of the procedure shorter than that for the intraoral approach. ${ }^{[25,26]}$ The major advantage of the intraoral approach is the lack of facial scarring and facial nerve palsy, whereas the major disadvantage is less visualization. Kellman stated that alignment of the posterior border is a reliable finding for a fracture reduction that can be evaluated more precisely via a submandibular approach. ${ }^{[20]}$

In our initial cases, we used intraoral incisions as a major port. However, achieving the proper orientation to reduce the fracture was challenging; thus, we used a submandibular incision as a second major port. In later cases, it was decided to use a submandibular incision as the major port, which allows for significantly better visualization and orientation. None of the patients developed permanent facial nerve palsy, and only one case of transient nerve weakness occurred. As application of endoscopic assistance reduced the size of the required incision, the final scar with regard to external approach was smaller.

The direction of the proximal fragment displacement is an important factor when assessing the applicability of intra- or extraoral approaches. Chen et al. ${ }^{[16]}$ reported that endoscopic subcondylar fracture repair is particularly easy to perform in patients presenting with lateral override at the fracture site. In contrast, a medial override subcondylar fracture is particularly difficult to repair. Mueller ${ }^{[12]}$ reported that lateral displacement of the proximal segment is the most favorable for endoscopic repair of subcondylar fractures and that medial override of the proximal fragment is considered a contraindication. Schön et al. treated 17 patients using both intra- and extraoral approaches and reported that the intraoral approach was a reliable method for reducing fractures, even laterally displaced subcondylar fractures. He stated that the extraoral approach is indicated for severely dislocated fractures and medially displaced subcondylar fractures. In view of this knowledge, we still employed extraoral approach in cases with lateral displacement. The main cause for this otherwise "over precise" way of fixing subcondylar fractures was our desire to synergize the advantages of endoscopic assistance with the abilities of an extraoral approach.

Limited angulation and minimal medial overriding of the proximal fragment can be reduced endoscopically. We achieved reduction of medially displaced subcondylar fractures in two cases. One case had limited medial displacement and the other had minimal overriding of the proximal fragment. Many authors use an intraoral approach to treat medially displaced subcondylar fractures. However, the intraoral approach has not been adopted as a routine technique due to its higher technical difficulty compared to extraoral approaches, which also provide better visibility. ${ }^{[1,22,33]}$ In fact, whatever method is used, the endoscopic approach is technically challenging, and there is a steep learning curve. Medially displaced subcondylar fractures in six patients could only be plated after conversion to a full open approach as a bail-out procedure, and one endoscopically operated case with inadequate reduction on one side was subsequently reoperated.

Troulis and Kaban ${ }^{[25]}$ reported $60 \mathrm{~min}$ and Lauer and Schmelzeisen $^{[24]}$ reported $210 \mathrm{~min}$ for conducting the extraoral approach. Using an intraoral approach, Miloro ${ }^{[1]}$ and Lee et al..$^{[6]}$ reported 109 \pm 32 and $143 \pm 63 \mathrm{~min}$, respectively. The mean operating time in our cases was $150 \mathrm{~min}$. These operation times are shorter than those of open reduction for subcondylar fracture treatment. In fact, the difficulty of fracture reduction in a limited two-dimensional visual field and the long 
learning curve are the major drawbacks of endoscopy for subcondylar fractures. Kellman ${ }^{[35]}$ pointed out that once experience has been gained, the procedure can be performed in a reasonable amount of time. The use of specialized equipment also seems to be a disadvantage of the endoscopic technique as monitors, light sources, and other equipment are currently available in most operating rooms. However, proper instruments such as retractors, plate holders and specific trocars are important for successful completion of the entire procedure.

The $1.5-\mathrm{mm}$ mini-plates were used for fracture reduction because they allow a particular degree of malleability during adaptation. Two plates were utilized for fracture stabilization if possible. MMF was performed 14 days later in six cases in whom fracture stability was questionable.

In conclusion, an extraoral endoscopic approach for subcondylar fractures is feasible and can be carried out with decreased morbidity. This approach is recommended for those with limited experience in endoscopy to treat low laterally displaced subcondylar fractures as their initial cases, and the extraoral approach can be used as the major port.

\section{Conflict of interest: None declared.}

\section{REFERENCES}

1. Ellis E 3rd, Moos KF, el-Attar A. Ten years of mandibular fractures: an analysis of 2,137 cases. Oral Surg Oral Med Oral Pathol 1985;59:120-9.

2. Dahlström L, Kahnberg KE, Lindahl L. 15 years follow-up on condylar fractures. Int J Oral Maxillofac Surg 1989;18:18-23.

3. Ellis E 3rd, Dean J. Rigid fixation of mandibular condyle fractures. Oral Surg Oral Med Oral Pathol 1993;76:6-15.

4. Ellis E 3rd, Simon P, Throckmorton GS. Occlusal results after open or closed treatment of fractures of the mandibular condylar process. J Oral Maxillofac Surg 2000;58:260-8.

5. Ellis E, Throckmorton GS. Treatment of mandibular condylar process fractures: biological considerations. J Oral Maxillofac Surg 2005;63:11534.

6. Walker RV. Condylar fractures: nonsurgical management. J Oral Maxillofac Surg 1994;52:1185-8

7. Widmark G, Bågenholm T, Kahnberg KE, Lindahl L. Open reduction of subcondylar fractures. A study of functional rehabilitation. Int J Oral Maxillofac Surg 1996;25:107-11.

8. Zide MF, Kent JN. Indications for open reduction of mandibular condyle fractures. J Oral Maxillofac Surg 1983;41:89-98.

9. Jacobovicz J, Lee C, Trabulsy PP. Endoscopic repair of mandibular subcondylar fractures. Plast Reconstr Surg 1998;101:437-41.

10. Mueller R. Endoscopic treatment of facial fractures. Facial Plast Surg 2008;24:78-91.

11. Miloro M. Endoscopic-assisted repair of subcondylar fractures. Oral Surg Oral Med Oral Pathol Oral Radiol Endod 2003;96:387-91.

12. Mueller RV. Endoscopic mandible fracture management: Techniques. In: Mathes SJ, Hentz VR, editors. Mathes plastic surgery. Philadelphia PA: Saunders; 2005. p. 511-40.

13. Miloro M. Considerations in subcondylar fracture management. Arch
Otolaryngol Head Neck Surg 2004;130:1231-2.

14. Arcuri F, Brucoli M, Baragiotta N, Benech R, Ferrero S, Benech A. Anal$y$ sis of complications following endoscopically assisted treatment of mandibular condylar fractures. J Craniofac Surg 2012;23:196-8.

15. Weinberg MJ, Merx P, Antonyshyn O, Farb R. Facial nerve palsy after mandibular fracture. Ann Plast Surg 1995;34:546-9.

16. Lee C, Mueller RV, Lee K, Mathes SJ. Endoscopic subcondylar fracture repair: functional, aesthetic, and radiographic outcomes. Plast Reconstr Surg 1998;102:1434-45.

17. Chen CT, Lai JP, Tung TC, Chen YR. Endoscopically assisted mandibular subcondylar fracture repair. Plast Reconstr Surg 1999;103:60-5.

18. Schön R, Schramm A, Gellrich NC, Schmelzeisen R. Follow-up of condylar fractures of the mandible in 8 patients at 18 months after transoral endoscopic-assisted open treatment. J Oral Maxillofac Surg 2003;61:4954.

19. Kellman RM. Endoscopically assisted repair of subcondylar fractures of the mandible: an evolving technique. Arch Facial Plast Surg 2003;5:24450 .

20. Kellman RM. Endoscopic approach to subcondylar mandible fractures. Facial Plast Surg 2004;20:239-47.

21. Schön R, Fakler O, Gellrich NC, Schmelzeisen R. Five-year experience with the transoral endoscopically assisted treatment of displaced condylar mandible fractures. Plast Reconstr Surg 2005;116:44-50.

22. Cho-Lee GY, Rodríguez Campo FJ, González García R, Muñoz Guerra MF, Sastre Pérez J, Naval Gías L. Endoscopically-assisted transoral approach for the treatment of subcondylar fractures of the mandible. Med Oral Patol Oral Cir Bucal 2008;13:511-5.

23. Mueller RV, Czerwinski M, Lee C, Kellman RM. Condylar fracture repair: use of the endoscope to advance traditional treatment philosophy. Facial Plast Surg Clin North Am 2006;14:1-9.

24. Lauer G, Schmelzeisen R. Endoscope-assisted fixation of mandibular condylar process fractures. J Oral Maxillofac Surg 1999;57:36-40.

25. Troulis MJ, Kaban LB. Endoscopic approach to the ramus/condyle unit: Clinical applications. J Oral Maxillofac Surg 2001;59:503-9.

26. Troulis MJ. Endoscopic open reduction and internal rigid fixation of subcondylar fractures. J Oral Maxillofac Surg 2004;62:1269-71.

27. Schön R, Gutwald R, Schramm A, Gellrich NC, Schmelzeisen R. Endoscopy-assisted open treatment of condylar fractures of the mandible: extraoral vs intraoral approach. Int J Oral Maxillofac Surg 2002;31:23743.

28. Schubert W, Jenabzadeh K. Endoscopic approach to maxillofacial trauma. J Craniofac Surg 2009;20:154-6.

29. Schoen R, Fakler O, Metzger MC, Weyer N, Schmelzeisen R. Preliminary functional results of endoscope-assisted transoral treatment of displaced bilateral condylar mandible fractures. Int J Oral Maxillofac Surg 2008;37:111-6..

30. Ducic Y. Endoscopic treatment of subcondylar fractures. Laryngoscope 2008;118:1164-7.

31. González-García R, Sanromán JF, Goizueta-Adame C, RodríguezCampo FJ, Cho-Lee GY. Transoral endoscopic-assisted management of subcondylar fractures in 17 patients: an alternative to open reduction with rigid internal fixation and closed reduction with maxillomandibular fixation. Int J Oral Maxillofac Surg 2009;38:19-25.

32. Domanski MC, Goodman J, Frake P, Chaboki H. Pitfalls in endoscopic treatment of mandibular subcondylar fractures. J Craniofac Surg 2011;22:2260-3.

33. Schmelzeisen R, Cienfuegos-Monroy R, Schön R, Chen CT, Cunningham L Jr, Goldhahn S. Patient benefit from endoscopically assisted fixation of condylar neck fractures--a randomized controlled trial. J Oral 
Maxillofac Surg 2009;67:147-58.

34. Veras RB, Kriwalsky MS, Eckert AW, Schubert J, Maurer P. Long-term outcomes after treatment of condylar fracture by intraoral access: a func- tional and radiologic assessment. J Oral Maxillofac Surg 2007;65:1470-6.

35. Kellman RM, Cienfuegos R. Endoscopic approaches to subcondylar fractures of the mandible. Facial Plast Surg 2009;25:23-8.

\section{KLINIK ÇALIŞMA - ÖZET}

\section{Mandibular subkondil kırıkların onarımında endoskop yardımı ve ağız dışından yaklaşımın sinerjisi: 13 olgu deneyimi}

\section{Dr. Lütfi Eroğlu, ${ }^{1}$ Dr. İbrahim Alper Aksakal, ${ }^{1}$ Dr. Musa Kemal Keleş, ${ }^{1}$ Dr. Çağlayan Yağmur, ${ }^{2}$ Dr. Ozan Aslan, ${ }^{3}$ Dr. Tekin Şimşek ${ }^{1}$}

${ }^{1}$ Ondokuz Mayıs Üniversitesi Tıp Fakültesi, Plastik Rekonstrüktif ve Estetik Cerrahi Anabilim Dalı, Samsun
${ }^{2}$ Samsun Eğitim ve Araştırma Hastanesi, Plastik Rekonstrüktif ve Estetik Cerrahi Kliniği, Samsun

${ }^{3}$ Samsun Gazi Devlet Hastanesi, Plastik Rekonstrüktif ve Estetik Cerrahi Kliniği, Samsun

AMAÇ: Maksillofasiyal travma tek başına veya diğer travmalara eşlik edecek şekilde görülebilir. Bu travmalarda mandibula kırığı görülme oranı yüksektir. Mandibulanın tüm kırıkları arasında subkondil bölgesine ait kırıklar özel bir yaklaşım gerektirir. Açık redüksiyonla yapılan internal sabitlemelerde; yüzde istenmeyen skar oluşumu, geçici/kalıcı fasiyel sinir felci gibi ek morbiditeler oluşabilir. Subkondil kırıklarında endoskopik yaklaşımla bu sorunları azaltmak mümkündür.

GEREÇ VE YÖNTEM: Çalışmamızda birbirini takip eden 13 hastadaki subkondil kırıklarına ağız dışından endoskopik yaklaşımla gerçekleştirdiğimiz onarımlara ilişkin tecrübelerimizi aktarmayı amaçladık. Ocak 2010 ve Haziran 20II tarihleri arasında Ondokuz Mayıs Üniversitesi Tıp Fakültesi Hastanesi Plastik Rekonstrüktif ve Estetik Cerrahi Kliniği’ne acilden başvuran I 3 hastadaki I 5 subkondiler kırık bu çalışmaya dahil edildi.

BULGULAR: Hastalara endoskopik veya açık yaklaşım kullanılarak girişimde bulunuldu. Kırıklardan dokuz tanesine ağız dışından yapılan endoskopik yaklaşımla başarılı biçimde plak-vida sabitlemesi yapıldı. Endoskopik onarım yapılan kırıkların yedi tanesinde proksimal parçalar laterale deplaseydi. Kırıkların geri kalan altı tanesine ise endoskopik olarak başlandıktan sonra tam açık yaklaşıma dönülerek girişim yapıldı. Bu altı kırığın hepsinde de proksimal parçalar mediyale deplase haldeydi.

TARTIŞMA: Subkondil kırıklarında ağız dışından endoskopik yaklaşımla onarım yapmak mümkündür. Bu yaklaşımda amaç işleme bağlı ek morbiditeyi etkili biçimde azaltmaktır. Endoskopik cerrahi ile tecrübesi az olan meslektaşlarımıza tavsiyemiz başlangıç olgusu olarak laterale deplase olmuş düşük seviyedeki subkondil kırıklarını seçmeleridir.

Key words: Endoskopi, endoskopik asistans, subkondiler kırık, subkondil kırığı.

Ulus Travma Acil Cerr Derg 2013;19(5):434-440 doi: 10.5505/tjtes.2013.77292 